\title{
Reading Transpacific American Literature: Empire, Space, and Representation
}

\section{Yuan Shu and Sharmani Patricia Gabriel}

Texas Tech University, USA and Universiti Malaya, Malaysia

Why transpacific American literature now? What does transpacific American literature mean at a moment when Cold War 2.0 is in full swing? How do we understand the geopolitics of the transpacific from the unique locations of East and Southeast Asia, Oceania, and North America, which Yến Lê Espiritu, Lisa Lowe, and Lisa Yoneyama historicise and theorise in terms of "transpacific entanglements"? In this special issue, we seek to intervene in the emerging field by reimagining a moment of transformation of the Asia Pacific from a space of imperial fantasy and competition to multiple sites of resistance and engagement animated by movements of people, flows of commodities, and exchange of ideas across the region (Hoskins and Nguyen, Roberts and Stephens, and Shu "Oceanic Archives").

The impetus for this special issue was our belief that there were particular questions that warranted our continued reflection and consideration: How do we understand the transpacific in terms of political, economic, and cultural possibilities in relation to the intensifying obsession with "the rise of China" in our current moment as well as to earlier critical engagements with Cold War formations? How does the paradigm shift from the transatlantic to the transpacific illuminate our understanding of emerging sensibilities and subjectivities? What impact does the transpacific have upon our global imaginaries and planetary consciousness? How can the cultural productions of the Asia Pacific and their meanings be mobilised as alternatives to help us think beyond Eurocentric or US-centric assumptions of the world, such as that embedded in the operation of World Literature? What new or restored forms of knowledge, theorising, and praxis can the idea of the transpacific generate?

We begin by rethinking the present moment as a post-American world, a notion which was first articulated by media critic Fareed Zakaria in 2008 to designate "the rise of the rest," rather than as an "anti-American" sentiment or "the decline of the West" (Zakaria 5). His claim seemed to gain momentum when the Chinese state launched "the Belt and Road Initiative 


\section{SARE, Vol. 58, Issue 2 | 2021}

(BRI)," which was first unveiled by President Xi Jinping in his lecture at Nazarbayev University in the Kazakh capital, Astana (renamed Nur-Sultan), and then elaborated in his address to the Indonesian parliament in Jakarta a month later in 2013. As the two spots of enunciation were carefully selected by the Chinese state to signify both land and sea components of the initiative known as "the Silk Economic Belt" and "the Twenty-First-Century Maritime Silk Road", the BRI has captured tremendous global interest and imagination. While some critics purchase the Chinese state theory, which emphasises the economic underpinning of the BRI with attention to outlets for China's excess production capacity, others interpret the initiative as China's major geostrategic gesture to break the US encirclement in the Asia Pacific and constrain the rise of India as the next world factory. Still others perceive the project as Chinese efforts to augment their economic and political influence with a soft power narrative that would present "China as an alternative leader to the global hegemony of the United States" (Clarke 72). As one Portuguese government official bluntly put it, "the Belt and Road is the Chinese plan to build a new world order replacing the US-led international system" (Maçães $5)$.

If the BRI has been preoccupied with an economic interest in infrastructure construction aimed at connectivity among under-developed countries in the South Pacific as well as in West and Southeast Asia, what kind of critical role does China play in "the rise of the rest" vis-à-vis the US-centred world order? Does China's growing investment and movement in the Asia Pacific follow a similar pattern, which historian Paul Kennedy describes as "the rise and fall of the great powers," and in that sense perform a similar neocolonial function of extracting natural resources and expanding foreign markets in third world countries once colonised by Western powers? Or do these activities inaugurate a new historical moment in the true spirit of the 1955 Bandung Conference which could reckon with what Arif Dirlik critiques as "Pacific contradictions" (Dirlik "Introduction”)? In his 2007 book, Adam Smith in Beijing, Giovanni Arrighi contests "the rise of the rest" as a narrative that would "creat[e] conditions most favourable than ever before for a new Bandung to bring into existence the commonwealth of civilizations that Smith envisioned long ago" (384).

Indeed, "the rise of the rest" has raised important questions on the changing geopolitics of the transpacific, which have implications for the US-centred global order and its promoted values of democracy and human rights. If the Silk Economic Belt points to H. J. Mackinder's vision of the Eurasian landmass as "the geographical pivot of history" for Europeans in the late 


\section{SARE, Vol. 58, Issue 2 | 2021}

nineteenth and early twentieth centuries, then the "Twenty-First-Century Maritime Silk Road" has equally alarmed US geopolitical strategists, who have taken for granted US sea power in the Asia Pacific for over a century. As Yuan Shu and Donald Pease argue elsewhere, the United States has looked backward to the Atlantic world as the origins of US history and civilization but moved forward to the Pacific as the future of US economic and military expansions, which serve as an extension of the conquest of the Americas in the Western history of consciousness (Shu and Pease "Transnational American Studies" 13; Dirlik "The Asia-Pacific Idea").

Indeed, the Pacific did not register in Anglo-American consciousness until the late nineteenth century, when Alfred Mahan proposed sea power and a dominant US presence in the Asia Pacific as critical for the rise of the United States as a global power. Collaborating with Theodore Roosevelt, who had been instrumental in the 1898 conquest of the Philippines and annexation of the Hawaii Islands as the assistant secretary of the navy at the time, Mahan revolutionised the concept of enhancing military power to safeguard ocean and sea lanes on the one hand and provided geopolitical and intellectual justifications for transforming the Pacific into an American lake on the other. It is precisely in this sense that Christopher Connery critiques Mahan's theory and practice as the foundation of US imperialism: "Mahan is centrally responsible for the U.S. posture of constant military preparedness and the posture of imminent global war, which has characterised so much of our century" ("Ideologies of Land and Sea" 183).

Following on from Mahan's vision of sea power and supplemented by Mackinder's notion of the Eurasian landmass, the geopolitical theorist Robert Kaplan has authored numerous articles and books, from "How We Would Fight China" in 2005 to Asia's Cauldron: The South China Sea and the End of a Stable Pacific in 2014. What centres his arguments is how to secure all the strategically important spots around the globe to sustain empire and monitor the rise of potential competitors such as China. It was in this spirit that President Obama first announced the pivot back to Asia in Australia in November 2011, which had first been elaborated by then Secretary of State Hillary Clinton in her essay, "America's Pacific Century." Modelled on Henry Luce's 1941 Life magazine essay, "The American Century," Clinton envisions enhancement of US military, economic, and political power in the economically and culturally vibrant and dynamic Asia Pacific and considers control of the largest markets and populations in the region as central to the future of the US empire. Because the United States has reinforced rather than loosened its Cold War hub-and-spoke system of 


\section{SARE, Vol. 58, Issue 2 | 2021}

bilateral military alliances and the forward-deployed military capabilities in the Asia Pacific, Bruce Cumings cannot help but raise a rhetorical question at the move: "But why play in the pivot-why pivot at all—when you control the court?" (251). In the same vein, in his critique of what he calls the American way of empire, Thomas Bender further observes that the openly racist rhetoric of empire of the nineteenth century has gradually been replaced by a new vocabulary of "order," "development," "responsible government," "economic efficiency," and "freedom and democracy" (55).

What "the rise of the rest" ultimately exposes in the Asia Pacific is the fact that the US archipelago of bases, which, hidden in plain sight, have neutered what Cumings perceives as "the operation of realpolitik among its major allies such as Japan and South Korea" and rendered a Westphalian system totally impossible in the region (Cumings 250). In this light, the threat that China's Belt and Road Initiative poses for the United States is to reverse the process of what Michael Hardt and Antonio Negri call "Empire," a self-fashioning "network power" aiming to implement and expand the constitutional project of the United States on a global scale. At what political scientist Graham Allison calls a new "Thucydides's Trap," we may have a glimpse of the spectre of the "clash of civilizations and remaking of world order" envisioned by Samuel Huntington. If China fails to address social equality and ecological sustainability in its own country and "the rise of the rest" turns out to be "the hype of the rest," Arrighi portrays two contrasting scenarios for our future- "China may well turn into a new epicentre of social and political chaos that will facilitate Northern attempts to re-establish a crumbling global dominance" or China may "help humanity burn up in the horrors (or glories) of the escalating violence that has accompanied the liquidation of the Cold War world order" (389). Since the Trump administration had escalated the trade war between the United States and China into a tech war and a new ideological war starting in 2018, the conflict between the two countries has again dominated the geopolitics of the transpacific, creating a strong sense of déjà vu and serving as the de facto Cold War 2.0 (Tharoor).

Speaking of US-China tensions in relation to the geopolitics and the future of the Asia Pacific, Prime Minister Lee Hsien Loong of Singapore made a statement that may well reflect the concerns and perspectives of Southeast Asian countries: "Their success - and the prospect of an Asian century-will depend greatly on whether the United States and China can overcome their differences, build mutual trust, and work constructively to uphold a stable and peaceful international order. This is a fundamental issue of our time." What Lee articulated at 


\section{SARE, Vol. 58, Issue 2 | 2021}

this historical juncture is a sentiment if not an anxiety that Southeast Asia does not want to witness another Cold War being played out in the region or it may have to choose one side over the other even though Singapore and many other countries have historically and politically sided with the United States and arguably been the beneficiaries of the US-centred world order.

It is precisely at this moment of danger that we should revisit what Espiritu, Lowe, and Yoneyama theorise as the geopolitical, military, and epistemological entanglements in the US encounter with the Asia Pacific. They make specific connections between empire and militarism, a settler state and a racial state, and expansionism and neoliberal capitalism. They note:

This U.S. settler logic intersects with racialized capitalism and overseas empire asserts itself-often through the collaborative networks of the U.S.-backed, patriarchally organized, subimperial Asian "client-states"in transpacific arrangements such as: export processing zones in the Philippines, U.S. military bases in Okinawa and Guam, nuclear test sites in the Marshall Islands, the exportation of nuclear power plants throughout Asia, the partition of Korea, and the joint military operations that demonstrate and secure the empire's reach. (175-76)

Against this background of the changing geopolitics of the transpacific since the nineteenth century, how do we understand transpacific American literature? If nineteenth-century AngloAmerican literature explored and critiqued American adventurism and expansionism into the Pacific as an extension of the American westward movement and development of American capitalism, which was best represented by the works of Edgar Allan Poe, Herman Melville, and Jack London, among others, then twentieth-century American literature and culture manifested strong traces of US military intervention in the Asia Pacific, which had encompassed the Pacific Theatre of World War II and the Korean War but culminated in the Vietnam War. Like much of nineteenth-century Anglo-American literature's preoccupation with the civilising mission in the South Pacific, twentieth-century American literature on the Vietnam War was often complicit with Cold War Orientalism, which replaced the urgent issue of decolonization and de-imperialization in the region at the end of World War II with a new narrative on the global conflict between democracy and totalitarianism (Kuan-Hsing Chen). Above all, these texts typically represented American soldiers as "protectors of democracy, 


\section{SARE, Vol. 58, Issue 2 | 2021}

liberty, and equality" vis-à-vis the "protected" in the Asia Pacific as inferior, subordinated, belated, and indebted (Espiritu et al).

Following what Shelley Fisher Fishkin calls the transnational turn in American studies, Asian American literature has been playing a more critical role in the formation and development of transpacific American literature. From Sui Sin Far's Mrs. Spring Fragrance and Other Writings (1912) to Maxine Hong Kingston's China Men (1980), from Carlos Bulosan's America is in the Heart (1943) to Theresa Hak Kyung Cha's Dictée (1982), from John Okada's No-No Boy (1957) to Viet Nguyen's The Sympathizer (2015), Asian American literature has not only documented the transpacific experiences of diverse ethnic groups at different historical and political moments since the late nineteenth century, but it has also provided an alternative way of approaching and appropriating American experiences, from the Asia Pacific to North America and from the west coast to the east coast, which in reverse foreground the process of American nation-building and empire-building. In what Mai-Linh K. Hong calls the "new Vietnamese American literature", a new generation of Asian American authors have challenged Cold War American studies by foregrounding its ideological preoccupations and interrogating the politics of the global culture industry with special attention to critical refugee studies and environmental critiques.

To extend the frame of analysis and capture the plenitude of methodologies, concerns, and approaches in the field of transpacific American studies in our contemporary moment, this special issue of SARE (6 articles, an interview feature, and a poem) builds upon yet also challenges older models of hegemony, normative histories, taken for granted geographies, and established cartographies, including the analytic of the "transpacific" itself. The collection demonstrates how a transpacific framework can be deployed across diverse perspectives in academic writing and from varied locations, with our scholars and activists working from the United States, Australia, Iran, Taiwan, and Malaysia. We are privileged to have among our contributors seminal thinkers and scholars in the field of transpacific American studies and are delighted that the synergistic creativity of the transpacific as a critical vantage point has enabled new connections and solidarities, paving the way for further studies in the field. The topics examined include the Hiroshima bomb, post-nuclear Japan, feminist collaboration, US imperialism, Cold War Orientalism, settler colonialism, the Vietnam War, diaspora, issues of representation, communal and personal memory, decolonial methodology, refugee histories, cultures and epistemologies, and the transnational family. 


\section{SARE, Vol. 58, Issue 2 | 2021}

If the emergence of transpacific American studies in the early twenty-first century was shaped in part by realignments in world systems of power, the contributions that follow remind us that the field itself is dynamic and ever changing, unsettling old binaries and hegemonizing ways of thought and imagining so as to reflect newer forms of imperialism, renewed understandings of alterity and difference, and the inherently entangled and crossboundary orientation of Asian identity in America. The way the rubric of the transpacific has been utilised, how it is defined, and the purposes it serves are, as might be expected of any undertaking of this nature and the diverse and contested nature of the field, not uniform in the collection.

The opening piece by Paul Giles begins by mobilising a personal trajectory of "crossover" from Oxford to Sydney as a way of launching into a consideration of the complexities, epistemological as well as geographic and structural, involved in formulating and teaching a university course on Transpacific American Literature. In doing so, it draws our attention to the implications of mapping or framing the field. Proposing that we study the relationship between the transpacific and its predecessor, the transatlantic, in intertextual terms, Giles views both ways of mapping as two different yet also dialogical lineages in the study of American history, literature, and, more generally, American cultural, political, and environmental dominance over the course of many centuries. One of the reasons that Southeast Asia remains under-represented in US-dominated theories of World Literature, he argues, is because "the transpacific introduces a sense of alterity" that "remains difficult to accommodate within Anglophone norms." He also demonstrates how the decentring of US-dominant perspectives on time and space is effected through reversal - spatial, temporal, thematic as well as syntactic - in the writings of Maxine Hong Kingston. In this, he argues, lies the capacity of transpacific literature to reorient the compass of American studies. This leads him to conclude that the "transpacific" is not so much a classification as a method to reconfigure cartographies.

In the piece that follows, Nicholas O. Pagan investigates the implications of the transpacific paradigm on the institution of the family unit. He examines how transpacific immigration from China to America rewrites the rules that govern the transnational family and provides the conditions and possibilities for reshaping Asian American identity. Constructing his interpretative framework around Žižek's ideas on the distinction between explicit and implicit rules and the linking of ideology and social relations with the latter, Pagan explores the evolution of the family unit in Asian American fiction through the generations-in his 


\section{SARE, Vol. 58, Issue 2 | 2021}

reading of C.Y. Lee's The Flower Drum Song (1957) alongside Shawn Lee's Homebase (1979) and American Knees (1995) - through their fluctuating degrees of Chineseness in relation to how much they maintain allegiance to or break away from the initial set of rules underpinning the Chinese American family structure. The prefix "trans" in Pagan's delineation of the transnational Asian American family then not only subverts the fantasy of the "original" Chinese family by transgressing against the latter's rules but also points to the state of transition and transformation in Asian American subjectivity.

Rob Wilson attends to the transpacific in terms of the "unspeakable" violence and catastrophe associated with the "post-nuclear" World War II dynamics between the US and Japan. In his treatment of the Cold War repression of the memory of the Hiroshima bombing in the US political imaginary, trauma appears not just as catastrophic and unfathomable but is also reconfigured as a will to remember that produces a set of minor historiographies. In rewriting the dominant US Cold War historiography through a traumatic genealogy of America's role in the Pacific war, the cultural productions Wilson examines-principally, J.G. Ballard's Empire of the Sun (1984) and Kenzaburo Ōe's Hiroshima Notes (1965) — create an aesthetics of remembering at the periphery and reveal the forgotten historical sites of wounded survival and sociality that the dominant temporality of US imperialism has occluded. In forcing both America and its Cold War allies to confront the trauma of geopolitical domination and racialized hegemony-what Wilson, after the writings of Ōe, theorises as "Hiroshima sublime"-his paper delivers a powerful meditative critique of America's racial supremacy and ascendancy in the Pacific hinged on its "imperial right" to govern through the rhetoric of liberty, rights, and freedom, which necessitated Japan to be vanquished and reborn anew.

Transpacific trauma, present-day as well as ancestral, resurfaces in the poem

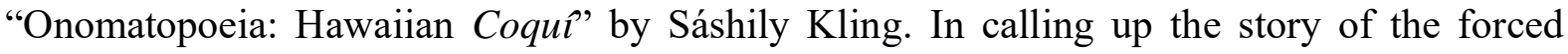
transplantation from their home of poor Puerto Rican workers as a cheap labour force for the sugarcane fields of Hawai' $i$, and their dehumanising treatment - their "brown bodies" with "veins (any gold, long gone) discolored, rusty, lost" - at the hands of their plantation owners, Kling's poem tracks the history of US imperialism back to its early (late nineteenth century) territorial expansions into the Pacific ocean and Caribbean sea. The palpable anger of its lines invokes the decimation of indigenous populations, the exploitation of migrant labour, and the displacement of people - and fauna - from their native lands, which attended the United States' shift from an agricultural to an industrial economy and its capitalist interventions in the Pacific. 


\section{SARE, Vol. 58, Issue 2 | 2021}

On a fundamental level, the poem commemorates the traumatic parallels between the loss, pain of dislocation, and suffering of the indigenous people of Hawaii and Puerto Rico but also their resilience, resistance, and regeneration despite their colonisation and slavery, as both cultures attempt to heal from the "homelessness and claustrophobia" perpetrated by the violence and brutality of US imperialism in the Pacific region.

The American Dream, turned "discolored [and] rusty" by the devastating consequences of the American investment in the Pacific, takes on a different hue by being approached from a different angle in the novel examined by Yuan Shu, which also addresses "the politics of remembering and forgetting" in the Asia Pacific raised in the earlier essay by Wilson. In grappling with the "state fantasy of American exceptionalism in the US military intervention in Vietnam", the article by Shu raises an intriguing problematic - How does one factor in the influence of Empire in the context of the improving political, economic, and military relations between the US and Vietnam in the interpretation of Vietnamese American literature? In doing so, the essay also moves to engage with the issue of the lack in American popular culture of the (South) Vietnamese perspective and response to the war in Vietnam, delineating the necessity to reorient a US-centred Vietnam War literature, and the attendant gaps in its cultural memory and representations, toward what Shu terms a "global Vietnam War literature," whilst also being mindful of the term's concomitant pitfalls. Towards this end and in his analysis of "arguably the first Vietnamese American novel," Lan Cao's Monkey Bridge (1997), Shu suggests that though the novel writes Vietnamese American women into literary existence and into the Asian American literary tradition, it does so by its problematic shoring up of the idea of America as the privileged site of personal success and transformation for its young Asian American narrator, reinscribing a version of the "model minority" myth embedded in the American Dream. In a similar vein, Shu argues, the novel rehabilitates Vietnam by domesticating the figure of the Vietcong into an assimilable non-white other for the marketplace of US culture, which is eager to consume what Viet Thanh Nguyen calls the "reconciliation narrative" $(2002,107)$ but is not prepared to confront the vexed social, political, cultural, and historical contexts that produced the tragedy of the American War in Vietnam. In reading Monkey Bridge as a novel that is desirous of inserting the Vietnamese perspective into American literature and culture and yet at the same time participates in a discourse of US multiculturalism that panders to the demands of the neoliberal global cultural industry, Shu uncovers the ambivalences unleashed by Empire that the transpacific may work to conceal. 


\section{SARE, Vol. 58, Issue 2 | 2021}

Still on the subject of turning the critical gaze on the United States' militarised presence in Southeast Asia, and the dominant American conception of Vietnam as "no more than a war", the interview by Fiona Lee and Amy Thanh Ai Tong with poet, scholar, and activist Lan Duong articulates, among other things, the imperative to delink or disengage Vietnamese refugees, and the figure of the refugee in general, from the sense of emergency, crisis, war, and calamity imposed on the refugee condition. It argues instead for the need to write refugees into a narrative that invites us to consider the "ongoingness of displacement" and the longer histories of colonialism, settler colonialism, and imperialism. Such a practice, for Duong, is crucial for it serves to reorient the transpacific paradigm around a renewed geopolitics of knowledge creation and as a space for alternative narratives and epistemologies. Reflecting on the significance of the emergent field of critical refugee studies and the Critical Refugee Studies collective, which she helped found, Duong cautions against the uncritical embrace of the received notion of refugee victimhood, as refugees are often relegated as victims of state violence or props in the drama of human migration by academia and the mainstream media. She contends that the idea of "refugee suffering" attests to the colonialist language and logic of apprehending the Other and as passive objects stripped off their voice and agency. In its place, Duong emphasises the necessity to (re)consider the figure of the refugee as a cultural subject and of cultivating a different way of engaging with refugeeism. She argues that refugee cultural creations and contributions can enable new forms of knowledge production. By bringing a decolonial methodology to bear on the US-centred conception of the transpacific as a paradigm of power and knowledge production, critical refugee studies recasts the "unspectacular" figure of the refugee from a passive object of study into a social actor, an agent of critique, and a producer of knowledge.

American military adventurism in Vietnam is also the focus of the paper by Mahdi Teimouri. In triangulating the connections to US imperialism in Viet Thanh Nguyen's The Sympathizer (2015) and J.M. Coetzee's “The Vietnam Project” (1974, as part of his debut novel Dusklands) and Waiting for the Barbarians (1980), Teimouri establishes the thematic parallels and overlaps that bring these texts in productive conversation with one another. While the congruences between the first two are more readily apparent, Teimouri argues that the third text resonates strongly with the concerns of the special issue when read as an allegory of Empire and therefore as a palimpsest of the spatial and temporal contexts of the other two novels. In the three texts he examines, each of which he argues "illuminates the inner workings of 


\section{SARE, Vol. 58, Issue 2 | 2021}

Empire", Teimouri focuses on a critique of the representational systems by which imperial power and violence is framed, maintained, and distributed. Toward this end, he foregrounds the ways in which the totalising strategies of imperialism work toward the annihilation of difference, bringing particular attention to bear on imperializing practices that justify brutality on the basis of the otherness of the non-"grievable", non-white, non-Western subjugated body.

In the closing piece, Chih-ming Wang appropriates the prominence-and promiseof return narratives in post-1990s Asian American literature to reconceptualize the transpacific in American studies and recalibrate the region's geopolitics through his coinage of a "post/Cold War" dynamic and its impact on Asian American literary production. Wang deploys the trope of return not only to reverse the default "arrival" motif in an earlier wave of Asian American literature and scholarship but to also undo the grounds of returning. Return, as Wang contends, "is as much a sign of connection as it is of division". More than a reversal of movement, then, Wang's rearticulation of Asian American literature through the configuration of "Asian Americans in Asia" contests the minority frame of representation, which has worked to obscure the emergent Americanness of Asian American subjectivity and cultural productions. It also resignifies the transpacific as a rubric that challenges Orientalism's binarisms and the old Cold War divisions by accounting for other movements, memories, and epistemologies within the region. Through his formulation and use of a "post/Cold War" rubric, rather than globalisation, as a temporal framework to analyse Maxine Hong Kingston's I Love a Broad Margin to My Life (2011) and Chang-rae Lee's My Year Abroad (2021), Wang posits a new model of transpacific imagining that is "unfastened" from the earlier Cold War logic of knowledge production, extending Asian American histories and subjectivities beyond the borders of the United States and beyond the US telos of immigration.

To the question posed at the opening of the Introduction- "Why transpacific American literature now?"- this special issue responds by setting out some of the key issues, questions, and problematics that have required, and continue to warrant, our consideration and analysis. Whether it claims the transpacific as a method, or as a fraught space of violent contact, conflict, and struggle, or as a trope of interstitiality that unsettles accepted notions of origins and the telos of movements, communities, belongingness, and refugeeness, the inherently critical and creative energy of this special issue offers active and engaged frameworks for the contemplation of the transpacific as an analytical site constituted of the entanglements produced by flows and movements of peoples, ideas, cultures, and capital across the 


\section{SARE, Vol. 58, Issue 2 | 2021}

treacherous yet also promissory waters that connect "Asia" and "America". But it also does more than that. By exploring what transpacific American literature and scholarship look like now, in the third decade of our twenty-first century, the collection demonstrates the multifarious implications of how the Pacific, as a complex network of power and domination as well as a region of consciousness, continues to be imagined and experienced.

\section{Works Cited}

Allison, Graham. 2017. Destined for War: Can America and China Escape Thucydide's Trap? Boston: Houghton Mifflin Harcourt.

Arrighi, Giovanni.2007. Adam Smith in Beijing: Lineages of the Twenty-First Century. New York: Verso.

Bender, Thomas. 2006. "The American Way of Empire.” World Policy Journal 23, no. 1:1561.

Chen, Kuan-Hsing. 2010. Asia as Method: Toward Deimperialization. Durham, NC: Duke UP.

Clarke, Michael. 2018. "The Belt and Road Initiative: China's New Grand Strategy." Asia Policy 24: 71-79.

Connery, Christopher L. 2001. "Ideologies of Land and Sea: Alfred Thayer Mahan, Carl Schmitt, and the Shaping of Global Myth Elements." boundary 2 28, no. 2: 173-201.

Cumings, Bruce. 2014. "China's Bullying No Match for US Pacific Power." Current History 113, Issue 764: 245-251.

DeLoughrey, Elizabeth M. 2007. Routes and Roots: Navigating Caribbean and Pacific Island Literatures. Honolulu: University of Hawai'i P.

Dirlik, Arif. 1998. "Introduction: Pacific Contradictions." What Is in a Rim? Critical Perspectives on the Pacific Region Idea. Ed. Arif Dirlik. Second Ed. New York: Rowman \& Littlefield Publishers. 3-13.

----. 1998. "The Asia-Pacific Idea: Reality and Representation in the Invention of a Regional Structure." What Is in a Rim? Critical Perspectives on the Pacific Region Idea. Ed. Arif Dirlik. Second Ed. New York: Rowman \& Littlefield Publishers. 15-36.

Fishkin, Shelly Fisher. "Crossroads of Culture: The Transnational Turn in American StudiesPresidential Address to the American Studies Association, November 12, 2004." American Quarterly 57:1 (2005): 17-57. 


\section{SARE, Vol. 58, Issue 2 | 2021}

Hardt, Michael, and Antonio Negri. 2000. Empire. Cambridge, Mass: Harvard UP.

Huntington, Samuel P. 1996. The Clash of Civilizations and Remaking of World Order. New York: Simon \& Schuster.

Lee, Hsien Loong. 2020. "The Endangered Asian Century: America, China, and the Perils of Confrontation." Foreign Affairs. June 4. https://www.foreignaffairs.com/articles/asia/2020-0604/lee-hsien-loong-endangered-asian-century.

Luce, Henry. 1941. “American Century.” Life. February 17. 61-65.

Maçães, Bruno. 2018. Belt and Road: A Chinese World Order. London: Hurst \& Company.

Mackinder, H.J. 1904. "The Geopolitical Pivot of History.” The Geographical Journal 23, no. 4: 421-437.

Mahan, A.T. 1890. The Influence of Sea Power upon History: 1660-1783.

Nguyen, Viet Thanh, and Janet Hoskins. 2014. "Introduction: Transpacific Studies: Critical Perspectives on an Emerging Field." Transpacific Studies: Framing an Emerging Field. Eds. Janet Hoskins and Viet Thanh Nguyen. Honolulu: U of Hawai'i P.

Roberts, Brian Russell, and Michelle Ann Stephens. 2017. "Archipelagic American Studies: Decontinentalizing the Study of American Culture." Archipelagic American Studies. Eds. Brian Russell Roberts and Michelle Ann Stephens. Durham, NC: Duke UP. 1-54.

Shu, Yuan. 2019. "Introduction: Oceanic Archives, Indigenous Epistemologies, and Transpacific American Studies." Oceanic Archives, Indigenous Epistemologies, and Transpacific American Studies. Eds. Yuan Shu, Otto Heim, and Kendall Johnson. Hong Kong: Hong Kong UP. 1-21.

Shu, Yuan, and Donald Pease. 2015. "Introduction: Transnational American Studies and the Transpacific Imaginary." American Studies as Transnational Practice: Turning toward the Transpacific. Hanover, NH: Dartmouth College P. 1-35.

Tharoor, Ishaan. 2020. "Is a U.S.-China Cold War already underway?" The Washington Post. May 14. https://www.washingtonpost.com/world/2020/05/15/is-us-china-cold-war-alreadyunder-way/.

Zakaria, Fareed. 2008. "The Rise of the Rest." The Post-American World. New York: Norton. 